\title{
Identifikasi Kecemasan Mahasiswa Kebidanan terhadap Pembelajaran Daring dalam Masa Pandemi COVID-19
}

\author{
Dian Furwasyih, Yulia Arifin, Nur Femi \\ Email: deemidwife@gmail.com \\ Prodi Kebidanan Program Sarjana dan Pendidikan Profesi Bidan Program Profesi \\ STIKes MERCUBAKTIJAYA Padang, Indonesia \\ Jl. Pondok Kopi Siteba Padang-442295
}

\begin{abstract}
Abstrak
Pandemi COVID-19 menimbulkan banyak permasalahan sosial masyarakat termasuk pada mahasiswa. Mahasiswa yang merupakan kelompok usia remajaharus beradaptasi dengan sistem pembelajaran daring. Remajamengalami kecemasan berupatekanan akademik, cemas tidak dapat mengikuti pembelajaran daring dengan baik, beban tugasdirasa semakin menumpuk, pembelajaran daring dirasa tidak efektif sebab tidak ada interaksi langsung dengan dosen, dan lain - lain. Studi deskriptif kuantitatif ini dirancang untuk mengidentifikasi kecemasan pada mahasiswa Program Studi Diploma III Kebidanan dan Prodi Kebidanan Program Sarjana dan Pendidikan Profesi Bidan Program Profesi STIKes MERCUBAKTIJAYA Padang. Kuisioner yangdimodifikasi dari formulir Hamilton Anxiety Rating Scale (HARS) disebarkan dalam bentuk google form kepada 138 mahasiswa Kebidanan. Data dianalisis menggunakan SPSS. Hasil penelitian menunjukkan hampir sebagian responden $(42 \%)$ berumur 19 tahun, hampir sebagian $(47,8 \%)$ berada di semester 2 atau tingkat 1 . Lebih dari separuh $(53,6)$ mahasiswa tinggal di tempat kost, dengan kondisi jaringan internet yang memadai sebesar 61,6\%.Lebih dari separuh $(59,4 \%)$ mahasiswa menyatakan cukup mampu mengerjakan tugas dengan komputer dan sebesar $63,7 \%$ menyatakan pembelajaran daring tidak efektif. Lebih dari separuh responden (54,3\%) mempunyai tingkat kecemasan sedang dalam menghadapi pembelajaran daring semasa pandemi COVID-19. Kecemasanini dapat direduksi dengan memberikan berbagailayanan konseling seperti layanan konseling individual, bimbingan dan konseling kelompok. Perguruan tinggi harus dapat memfasilitasi hal ini dengan layanan telekonsultasi bersama penasihat akademik maupun psikolog jika dibutuhkan apabila kecemasan mahasiswa berakibat buruk pada hasil belajar dan menimbulkan gangguan pada kesehatan mental mahasiswa.
\end{abstract}

Kata kunci: tingkat kecemasan; pembelajaran daring; pandemi COVID-19; mahasiswa kebidanan.

\begin{abstract}
The COVID-19 pandemic has caused many social problems for the community, including students. Students who are teenagers must adapt to the online learning system. Adolescents experience anxiety in the form of academic pressure, anxiety that they cannot follow online learning well, the task load is felt to be piling up, online learning is not effective because there is no direct interaction with lecturers, and so on. This quantitative descriptive study was designed to identify anxiety in students of the Diploma III Midwifery Study Program and Midwifery Study Program Undergraduate Program and Midwifery Professional Education Program STIKes MERCUBAKTIJAYA Padang. A modified questionnaire from the Hamilton Anxiety Rating Scale (HARS) form was distributed in google form to 138 Midwifery students. Data were analyzed using SPSS. The results showed that almost half of the respondents (42\%) were 19 years old, almost half $(47.8 \%)$ were in semester 2 or level 1 . More than half (53.6) of students lived in boarding houses, with adequate internet network conditions by $61.6 \%$. More than half $(59.4 \%)$ of students stated that they were quite capable of doing assignments with computers and $63.7 \%$ stated that online learning was not effective. More than half of the respondents $(54.3 \%)$ had a moderate level of anxiety in dealing with online learning during the COVID-19 pandemic. This anxiety can be reduced by providing various counseling services such as individual counseling services,
\end{abstract}


Jurnal Kebidanan Harapan Ibu Pekalongan

guidance and group counseling. Universities must be able to facilitate this with teleconsultation services with academic advisors and psychologists if needed if student anxiety adversely affects learning outcomes and causes disturbances to students' mental health.

Keywords: level of anxiety; online learning; COVID-19 pandemic; midwifery student.

\section{Pendahuluan}

Virus corona, SARS-CoV-2 pertama kali muncul di akhir tahun 2019 di kota Wuhan, Cina, dan terus menyebar ke penjuru dunia sepanjang tahun 2020 hingga saat ini. Tak terkecuali di Indonesia. Kasus pertama teridentifikasi di bulan Maret tahun 2020. Mulai saat itu terjadi banyak perubahan dalam tatanan hidup masyarakat Indonesia. $^{(1)}$

Secara statistik, Indonesia menempati peringkat ke $-15 \mathrm{di}$ dunia dengan kasus kumulatif COVID-19 yang tertinggi. Indonesia juga menjadi peringkat pertama (I) di dunia untuk jumlah kasus positif harian. ${ }^{(2)}$

Pandemi

COVID19 menimbulkan banyak permasalahan sosial masyarakat termasuk pada remaja. Kehidupan para remaja ikut terpengaruh seiring dengan dilakukannya kebijakan untuk mengurangi dampak dari pandemi ini. Keseharian masyarakat dunia menjadi terhambat dengan adanya pandemi ini. Aktivitas sepeti biasa dan bepergian menjadi hal yang terlarang dengan adanya penerapan social distancing dan physical distancing. Remaja yang merupakan kelompok pelajar dan mahasiswa harus beradaptasi dengan sistem pembelajaran daring yang diterapkan selama masa pandemi. Pembelajaran online merupakan bentuk upaya pemerintah dalam mengurangi jumlah korban akibat COVID19 yang menyebar dan mengalami peningkatan yang signifikan. Para remaja yang biasanya sering beraktivitas di luar rumah, sekarang terpaksa melakukan semua kegiatannya dirumah. $^{(3)}$

Masa remaja adalah masa transisi atau peralihan dari anak anak menuju dewasa yang di dalamnya mencakup kematangan mental, emosional, sosial, dan juga fisik. Secara psikologis, remaja adalah usia seseorang yang memasuki proses menuju usia dewasa. Masa remaja merupakan masa dimana mereka sudah tidak merasa bahwa dirinya anak - anak dan sudah sejajar dengan orang lain di sekitarnya walaupun orang tersebut lebih tua. ${ }^{(4)}$

Menurut Ali dan Arori (2006), faktor - faktor yang dapat mempengaruhi perkembangan emosi remaja diantaranya adalah perubahan jasmani, perubahan pola interaksi dengan orang tua, perubahan polainteraksi dengan teman sebaya, adanya perubahan pandangan luar, serta adanya perubahan interaksi dengan sekolah. ${ }^{(5)}$

Menurut WHO (2019), stress yang muncul selama masa pandemi COVID 19 bisa berupa rasa takut dan cemas mengenai kesehatan diri 
Jurnal Kebidanan Harapan Ibu Pekalongan

dan kesehatan orang terdekat, pola tidur/pola makan berubah, sulit berkonsentrasi, hingga menggunakan obat- obatan/narkoba. Remaja dengan situasi emosional yang sering berubah-ubah, juga mengalami kecemasan semasa pandemi. Remaja merasa terbebani dengan tekanan akademik, cemas tidak dapat mengikuti pembelajaran daring dengan baik, beban tugas yang dirasa semakin menumpuk, pembelajaran daring dirasa tidak efektif, dan interaksi belajar tidak ada selama masa pembelajaran daring. ${ }^{(6)}$

Berdasarkan

gambaran fenomena diatas penulis tertarik untuk mengidentifikasi tingkat kecemasan mahasiswi dalam menghadapi pembelajaran daring selama masa pandemi COVID-19.

\section{Metode Penelitian}

Metode yang digunakan dalam penelitian ini adalah kuantitatif deskriptif. Populasi penelitian ini adalah mahasiswa program studi Diploma III dan Prodi Kebidanan program Sarjana dan Pendidikan Profesi Bidan Program Profesi STIKes MERCUBAKTIJAYA Padang sebanyak 138 orang. Teknik sampling yang digunakan adalah total sampling yaitu seluruhpopulasi menjadi sampel. Instrumen yang digunakan adalah Kuesioner Kecemasan Hamilton Anxiety Rating Scale yang di transfer dalam bentuk digital (google form). Link google form dibagikan ke mahasiswa saat jam istirahat perkuliahan, mahasiswa diminta mengisi informed consent yang telah disiapkan dengan membubuhi tanda tangan digital. Analisis data menggunakan analisis deskriptif menggunakan komputerisasi. Data disajikan dalam bentuk tabel distribusi frekuensi untuk menggambarkan karakteristik mahasiswa dan kondisi mahasiswa selama menghadapi pembelajaran daring di masa pandemi COVID 19.

\section{Hasil Penelitian dan Pembahasan}

Hasil analisis univariat data karakteristik responden berupa umur dan tingkat atau semester perkuliahan, tempat tinggal, kondisi jaringan, kemampuan menggunakan komputer dan keefektifan pembelajaran daringserta tingkat kecemasan mahasiswa kebidanan terhadap pembelajaran daring dalam masa pandemi COVID-19 dijelaskan pada tabel berikut ini.

a. Karakteristik Responden

Tabel 1 Distribusi Frekuensi Responden Berdasarkan Umur, Tingkat/Semester Perkuliahan, dan Tempat Tinggal

\begin{tabular}{|c|c|c|}
\hline Klasifikasi & $\mathbf{n}$ & $\%$ \\
\hline \multicolumn{3}{|c|}{ Umur (tahun) } \\
\hline 18 & 10 & 7,2 \\
\hline 19 & 58 & 42,0 \\
\hline 20 & 47 & 34,1 \\
\hline 21 & 23 & 16,7 \\
\hline \multicolumn{3}{|c|}{ Tingkat/Semester } \\
\hline $\mathrm{I} / 2$ & 66 & 47,8 \\
\hline II / 4 & 40 & 29,0 \\
\hline III / 6 & 32 & 23,2 \\
\hline \multicolumn{3}{|c|}{ Tempat tinggal } \\
\hline Kost & 74 & 53,6 \\
\hline $\begin{array}{l}\text { Dengan } \\
\text { Orangtua }\end{array}$ & 64 & 46,4 \\
\hline Total & 138 & 100 \\
\hline
\end{tabular}

n : frekuensi, \% : persentase

\begin{tabular}{lr}
\multicolumn{1}{c}{ Tabel 1} & menunjukkan \\
karakteristik & responden \\
berdasarkan & umur, \\
tingkat/semester & perkuliahan
\end{tabular}


Jurnal Kebidanan Harapan Ibu Pekalongan

dan tempat tinggal. Penelitian ini mengungkapkan bahwa $42 \%$ responden berumur 19 tahun, $47,8 \%$ berada di semester 2 atau tingkat 1 , dan $53,6 \%$ mahasiswa tinggal di tempat kost.

Tabel 2 Distribusi Frekuensi Responden Berdasarkan Kondisi Jaringan

\begin{tabular}{lcc}
\hline \multicolumn{1}{c}{ Kondisi Jaringan } & $\mathbf{n}$ & $\mathbf{\%}$ \\
\hline Memadai & 85 & 61,6 \\
\hline Tidak Memadai & 53 & 38,4 \\
\hline Total & 138 & 100 \\
\hline
\end{tabular}

n : frekuensi, \% : persentase

Tabel 2 menunjukkan detail tentang kondisi jaringan internet yang ada di tempat tinggal mahasiswa dimana $61.6 \%$ memiliki kondisi jaringan internet yang memadai.

Tabel 3 Distribusi Frekuensi Responden Berdasarkan Kemampuan Menggunakan Komputer Dalam Membuat Tugas

\begin{tabular}{lcc}
\hline $\begin{array}{c}\text { Kemampuan } \\
\text { Membuat Tugas }\end{array}$ & n & \% \\
\hline Sangat Mampu & 32 & 23,2 \\
\hline Cukup Mampu & 82 & 59,4 \\
\hline Kurang Mampu & 24 & 17,4 \\
\hline Total & 138 & 100 \\
\hline
\end{tabular}

n : frekuensi, \% : persentase

Dari tabel 3 terlihat bahwa $59,4 \%$ mahasiswa menyatakan cukup mampu menggunakan computer dalam membuat tugas.
Tabel 4 Distribusi Frekuensi Responden Berdasarkan

Keefektifan Pembelajaran

Daring

$\begin{array}{lll}\text { Keefektifan } & \text { n } & \%\end{array}$

Pembelajaran Daring

\begin{tabular}{lcc}
\hline Efektif & 50 & 36,2 \\
\hline Tidak Efektif & 88 & 63,7 \\
\hline Total & 138 & 100 \\
\hline
\end{tabular}

n : frekuensi, \% : persentase

Tabel 5 Distribusi Frekuensi Responden BerdasarkanTingkat Kecemasan Mahasiswa Terhadap Pembelajaran Daring Dalam Masa Pandemi COVID19

\begin{tabular}{lcc}
\hline $\begin{array}{c}\text { Tingkat } \\
\text { Kecemasan }\end{array}$ & n & \% \\
\hline Rendah & 39 & 28,3 \\
\hline Sedang & 75 & 54,3 \\
\hline Tinggi & 24 & 17,4 \\
\hline Total & 138 & 100 \\
\hline
\end{tabular}

Tabel 4 dan 5 mengungkapkan pendapat mahasiswa tentang keefektifan pembelajaran daring dimana sebesar $63,7 \%$ menyatakan tidak efektif. Tingkat kecemasan mahasiswa Kebidanan terhadap pembelajaran daring dalam masa pandemi COVID-19) berada pada tingkat kecemasan sedang $(54,3 \%)$

\section{Pembahasan}

Hasil penelitian menunjukkan hampir sebagian responden (42\%) berumur 19 tahun, hampir sebagian responden $(47,8 \%)$ berada di semester 2 atau tingkat 1 danlebih dari separuh $(53,6)$ mahasiswa tinggal di tempat kost. Hasil penelitian ini sebanding dengan penelitian Hidayati (2019) tentang 
Jurnal Kebidanan Harapan Ibu Pekalongan

Tingkat Kecemasan terhadap Prestasi Akademik Pengurus Ikatan Mahasiswa yang menyatakan ratarata usia responden (52,2\%) 19 tahun, responden berada di semester 3 perkuliahan sebanyak $58,2 \%{ }^{(7)}$

Mahasiswa dalam penelitian ini semuanya berada dalam masa remaja. Masa remaja merupakan masa transisi yaitu masa dimana terjadi banyak perubahan di dalam diri remaja baik secara aspek fisik, emosional, dan kognitif. Masa remaja mengacu pada tahap pubertas hingga dewasa, termasuk pengalaman psikologis yang dialami pada periode ini. ${ }^{(8)}$

Masa remaja sering mengalami gejolak psikologis yang besar ketika menghadapi perubahan yang ada di dalam kehidupannya. Apalagi mahasiswa tingkat awal dimana mahasiswa tingkat awal mengalami masa adaptasi dari lingkungan sekolah ke lingkungan universitas. Pada masa pandemi ini pertama kalinya mahasiswa melakukan pembelajaran dengan sistem daring. Perubahan yang dialami remaja tersebut dapat menimbulkan kecemasan di dalam diri mereka. Apalagi remaja yang hidup sendirian di tempat kost. Mereka diharuskan bisa mengurus diri sendiri. Banyak yang perlu dipersiapkan, maka tidak sedikit mahasiswa yang memilih pulang kampung atau tinggal dengan orangtua agar proses pembelajaran daring semakin lancar.

Hasil penelitian juga menunjukkan kondisi jaringan internet untuk belajar daring berada dalam kategori memadai sebesar $61,6 \%$. Lebih dari separuh $(59,4 \%)$ kemampuan mahasiswa dalam menggunakan komputer untuk membuat tugas berada dalam kategori cukup mampu dan pendapat mahasiswa tentang keefektifan pembelajaran daring sebesar $63,7 \%$ menyatakan tidak efektif. Hasil penelitian ini sebanding dengan penelitian (9) tentang Pengaruh Kecemasan saat Pembelajaran Daring Masa Pandemi COVID-19 Terhadap Prestasi Belajar Mahasiswa yang menyatakan jaringan internet berada dalam kategori memadai sebesar $63,1 \%$. kemampuan mahasiswa dalam menggunakan komputer sebesar $73,6 \%$ berada dalam kategori mampu dan pembelajaran daring dinilai tidak efektif sebanyak $68,4 \%$.

Pembelajaran daring merupakan pembelajaran tanpa tatap muka secara langsung antara dosen dan mahasiswa. Pembelajaran daring dilakukan melalui video conference, e-learning atau distance learning. Pembelajaran daring merupakan hal yang baru, baik bagi mahasiswa maupun dosen sehingga membutuhkan waktu yang cukup lama untuk beradaptasi. ${ }^{(10)}$

Dengan pembelajaran daring, dosen banyak memberikan tugas kepada mahasiswa untuk mengukur sejauh mana mahasiswa mengerti dengan materi pembelajaran tersebut. Sehingga mahasiswa cemas dengan banyaknya tugas yang harus mereka kerjakan. Mahasiswa juga dituntut untuk bisa menggunakan berbagai aplikasi yang ada di komputer atau laptop dalam menyelesaikan tugas. Dengan adanya aplikasi dan mudahnya 
informasi yang didapat dengan menggunakan internet, maka mahasiswa dapat menyelesaikan tugas tanpa sepenuhnya memahami pelajaran sehingga keefektifan pembelajaran dengan daring dirasa tidak memuaskan. Apalagi jika memasuki jadwal ujian yang dilakukan secara daring atau online.

Mahasiswa yang belum sepenuhnya paham dengan materi akan mengalami kecemasan dengan ujian yang dihadapinya. Ujian yang dilakukan secara daring semakin membuat kecemasan mahasiswa meningkat dengan jaringan internetnya yang lancar atau tidak. Jika jaringan internetnya tidak lancar, maka akan membuat mahasiswa terlambat dalam pengumpulan ujiannya. Beberapa penelitian menunjukan bahwa mahasiswa mengalami stres baik selama periode sebelum ujian maupun saat berlangsungnya ujian. Dalam hal ini yang menjadi stressor utama ialah tekanan akademis dan ujian itu sendiri.

Hasil penelitian ini menunjukkan tingkat kecemasan mahasiswa terhadap pembelajaran daring dalam masa pandemi COVID-19 terdapat lebih dari separuh responden $(54,3 \%)$ berada pada tingkat kecemasan sedang. Hasil penelitian ini sejalan dengan penelitian Fitria (2020) yang menyatakan sebanyak $54 \%$ remaja mengalami tingkat kecemasan kategori berat pada masa pandemi Covid-19. ${ }^{(11)}$

Kecemasan (ansietas/ anxiety) adalah gangguan alam perasaan (affective) berkelanjutan, tidak mengalami gangguan dalam menilai realitas (Reality Testing Ability), kepribadian masih tetap utuh, dan perilaku dapat terganggu tetapi masih dalam batasan normal. Kecemasan merupakan reaksi emosional yang timbul oleh penyebab yang tidak spesifik yang dapat menimbulkan perasaan tidak nyaman dan merasa terancam. Keadaan emosi ini biasanya merupakan pengalaman individu yang subjektif yang tidak diketahui secara khusus penyebabnya. ${ }^{(12)}$

Tingkat kecemasan mahasiswa dalam penelitian ini berada dalam kategori sedang yang berarti mahasiswa mengalami kecemasan tetapi masih mampu fokus terhadap sumber kecemasan dan mampu melakukan aktivitas lain.Kecemasan yang dialami mahsaiswa ini dapat menyebabkankurang tidur, insomnia dan masalah tidur lainnya. Semakin sedikit tidur maka semakin besar tingkat kecemasan. Untuk mengatasi kurang tidur dapat dilakukan dengan fokus pada cara-cara untuk meningkatan kualitas tidur, dengan meningkatnya kualitas tidur maka dapat mengurangi anxiety.

Selain tidak bisa tidur kecemasan juga menyebabkan kesulitan untuk fokus. Pandemi COVID-19 ini telah mengancam kesehatan fisik dan psikis, dan cara hidup sehari-hari. Secara tidak sengaja, mahsiswa setiap hari terus mendengar berbagai berita yang menakutkan tentang dampak COVID-19 dan kemudian memikirkan cara-cara untuk melindungi diri dari virus ini. Karena dampak COVID-19 ini 
mahasiswa selalu berada di dalam rumah dan selama di rumah juga harus tetap fokus untuk belajar. Akibat pemberitaan COVID-19, pikiran menjadi tidak fokus dan sulit berkonsentrasi pada pelajaran. Cara untuk meningkatkan konsentrasi pada masa pandemi ini adalah dengan mengurutkan apa yang mesti dilakukan, serta jangan lupa juga untuk istirahat yang cukup. ${ }^{(13)}$

Kecemasan yang dialami mahasiswa pada masa pandemi COVID-19 ini tentu tidak bisa dibiarkan begitu saja. Untuk mengatasi kecemasan ini peran orangtua sangat dibutuhkan, diantaranya selalu mendampingi, memotivasi, memberikan pengetahuan tentang COVID-19 ini. Selain itu, dosen pembimbing di kampus dapat membantu mahasiswa dengan memberikan pelayanan seperti layanan konseling individual, bimbingan dan konseling kelompok. Berbagai pendekatan konseling dapat diterapkan dalam kegiatan ini.

\section{Kesimpulan}

Berdasarkan hasil penelitian diketahui bahwa identifikasi kecemasan mahasiswa kebidanan terhadap pembelajaran daring dalam masa pandemiCOVID-19 berada pada kategori sedang. Kecemasan pada mahasiswa ini diperparah dengan berada ditempat tinggal kost-kostan dengan sinyal yang kurang memadai dan pembelajaran daring yang dinilai kurang efektif. Kecemasan ini harusdireduksi dengan memberikan berbagai pelayanan konseling agar tingkat kecemasan mahasiswa tersebut dapat diperkecil.

Layanan yang dapat diberikan kepada remaja untuk menurunkan tingkat kecemasan dalam masa pandemi COVID-19 adalah layanan konseling individual, bimbingan dan konseling kelompok. Perguruan tinggi harus dapat memfasilitasi hal ini dengan layanan telekonsultasi bersama penasihat akademik maupun psikolog jika dibutuhkan apabila kecemasan mahasiswa berakibat buruk pada hasil belajar dan menimbulkan gangguan pada kesehatan mental mahasiswa.

\section{Daftar Pustaka}

[1] Setahun Pandemi di Indonesia, Apa Saja Penanganan Covid-19 yang Harus Dibenahi? [Internet]. [cited 2021 Jul 22]. Available from: https://www.kompas.com/sai ns/read/2021/03/02/1201008 23/setahun-pandemi-diindonesia-apa-sajapenanganan-covid-19-yangharus

[2] Posisi Indonesia pada Pandemi Covid-19 Dunia, Ada di Mana? [Internet]. [cited 2021 Jul 22]. Available from: https://www.kompas.com/tre $\mathrm{n} / \mathrm{read} / 2021 / 07 / 14 / 18300076$ 5/posisi-indonesia-padapandemi-covid-19-duniaada-di-mana-

[3] Sekar S, Ananda D, Apsari NC. Mengatasi Stress Pada Remaja Saat Pandemi Covid19. 2020;7(2):248-56. 
Jurnal Kebidanan Harapan Ibu Pekalongan

[4] Hurlock EB. Psikologi Perkembangan: Suatu Pendekatan Sepanjang Rentang Kehidupan. Jakarta: Erlangga; 2011.

[5] Ali, M. \& Asrori M. Psikologi Remaja, Perkembangan Peserta Didik. Jakarta: Bumi Aksara; 2006.

[6] World Health Organization (WHO). Mental Health During COVID-19 Pandemic. 2019.

[7] Hidayati E, Nurwanah $\mathrm{N}$. TINGKAT KECEMASAN TERHADAP PRESTASI AKADEMIK PENGURUS IKATAN MAHASISWA MUHAMMDIYAH. Indones J Heal Sci. 2019;3(1):13.

[8] Furwasyih D, Melinda C. Perempuan (a literature review of women's psychology through life cycle approach). 1st ed. Bandung: Ellunar Publisher; 2020. 31-35 p.
[9] Untari E. Pengaruh Kecemasan saat Pembelajaran Daring Masa Pandemi Covid 19 Terhadap Prestasi Belajar Mahasiswa STIKES WILLIAM Surabaya. Angew Chemie Int Ed 6(11), 951-952. 2020;04(20).

[10] Hakiman. Pembelajaran Daring Pada Mahasiswa. 2020;

[11] Fitria L, Ifdil I. Kecemasan remaja pada masa pandemi Covid -19. J Educ J Pendidik Indones. 2020;6(1):1.

[12] Janiwarty, B, Pieter HZ. Pendidikan Psikologi untuk Bidan Suatu Teori dan Terapannya. Yogyakarta: Rapha Publishing; 2013.

[13] Muyasaroh H. Kajian Jenis Kecemasan Masyarakat Cilacap dalam menghadapi Pandemi Covid 19. LP2M UNUGHA Cilacap. 2020;3. 